\title{
A study on socio- economic condition of Tharu tribes in Bahraich district of Uttar Pradesh in India
}

\author{
Kumari Jyoti \\ Department of Food, Nutrition and Public Health, Ethelind College of Home Science, Sam \\ Higginbottom University of Agriculture, Technology and Sciences, Allahabad-211007 (U.P.), India \\ Dubey Ritu \\ Department of Food, Nutrition and Public Health, Ethelind College of Home Science, Sam \\ Higginbottom University of Agriculture, Technology and Sciences, Allahabad-211007(U.P.), India \\ Bose Dipak Kumar \\ Department of Agricultural Extension and Communication, Sam Higginbottom University of \\ Agriculture, Technology and Sciences, Allahabad-211007 (U. P.), India \\ Vandana Gupta * \\ Department of Food, Nutrition and Public Health, Ethelind College of Home Science, Sam \\ Higginbottom University of Agriculture, Technology and Sciences, Allahabad-211007(U.P.), India \\ *Corresponding author. E-mail: jyoti.kumari383@gmail.com
}

\begin{abstract}
As per the census of 2011 the tribal population consists of $8.6 \%$ while it was $8.2 \%$ according to the census of 2001 in India. This paper addresses the socio-economic status of Tharu tribes in Bahraich district of Uttar Pradesh. The socio economic status is an important determinant of health, nutritional status, mortality and morbidity of an individual. Socio Economic Status also influences the accessibility, affordability, acceptability and actual utilization of available health facilities. To classify the socio-economic status of the respondents, Uday Pareek and Trivedi scale has been adopted with subject to preliminary test and slight modification as per the need of the study. Measuring the socio-economic conditions of Tharu tribes from Uday Pareek and Trivedi scale, it can be concluded that all the Tharu tribes belong to four categories viz: Upper Middle Class, Middle Class, Lower Middle Class and Lower Class. $0.28 \%$ respondent belonged to upper middle class, $5.33 \%$ were middle class, $75.56 \%$ belonged to lower middle class and $18.83 \%$ to lower class. The findings can be beneficial for implementing projects that can help in improving their situation of backwardness.
\end{abstract}

Keywords: Education, Income, Occupation schedule tribes, Socio economic scale

\section{Article Info}

DOI:10.31018/jans.v10i3.1785

Received: June 4, 2018

Revised: July 22, 2018

Accepted: August 1, 2018

\section{How to Cite}

Kumari, J. et al. (2018). A study on socio- economic condition of Tharu tribes in Bahraich district of Uttar Pradesh in India. Journal of Applied and Natural Science, 10(3): 939 - 944

\section{INTRODUCTION}

As per the census of 2011 the tribal population consists of $8.6 \%$ while it was $8.2 \%$ according to the census of 2001 in India. The tribes are known for their simplicity, truthfulness, honesty, love of freedom, uprightness, hospitality and love of nature. They have a cheerful disposition which is reflected in their exotic dance and music. They live in the forest, hills and naturally isolated regions. They are different in physical appearance as compared to all other common people. They worship strange Gods and have specific language, culture and traditions. They have been retaining their customs and regulations (Mishra and Padhan, 2008). Several studies conducted on various tribal population living in different parts of India have reported them to be socially ignorant, economically indifferent, but culturally rich, behaviourally simple and trust worthy, leading their life in lap of nature. Among the tribal groups their living style is different from each other. It is obvious that food problems and habits of different tribes are bound to be different from those living in urban and rural areas. The tribal society is endowed with a cultural heritage and bestowed liberally with bounties of nature. They are very primitive simple and innocent. Every tribal group has a specific pattern of life, having their own culture, artistic tradition, habits and customs (Pattanaik, 2007)

Distribution of Tharus: The Tharu is well known scheduled tribe of Uttar Pradesh. It was declared as scheduled tribe in U.P. in the year 1967, along with four other tribes. After independence, for the first time in June 1967, the President of India notified five tribes of U.P. viz Raji, Bhotia, Jaunsari, Tharu and Bhoksa as scheduled tribes. Four, out of these five tribes, namely Raji, Bhotia, Jaunsari and Bhoksa (Buxa) have now become a part of Uttarakhand, though some villages of the Bhoksas are still in district Bijnor of Uttar Pradesh. Tharu is well known scheduled tribe of Uttar Pradesh. Tharus mostly live in the Tarai belt of Uttar 
Pradesh. The Region covers five districts of Uttar Pradesh namely Lakhimpur Kheri, Balrampur, Bahraich, Shravasti and Maharajganj (Table 1). The socio economic status (SES) is an important determinant of health, nutritional status, mortality and morbidity of an individual. SES also influences the accessibility, affordability, acceptability and actual utilization of available health facilities (Agarwal et al,2005). Many socio economical factors are difficult to assess quantitatively but certain ecological factors like occupation, family income, housing, kitchen, family details are essential to be assessed as they bear direct relation with the nutritional status of the individual (Jelliffe and Jelliffe, 1989). Most of the tribal population of India lives in remote and forest areas are at a lower level of technological because of their relative backwardness, illiteracy, and poverty and complex problems (Sethia and Joshi, 1990). As pointed out by Ghosal (1986) the inaccessibility of the area and the isolated life led by its inhabitants have given rise to a maze of uninformed opinions and myths about the local tribesmen and their primitive way of life. The tribes have also been suffering from various forms of social discrimination and political isolation (Sharma, 1995).

The term socio-economic refers to a wide range of interrelated and diverse aspects relating to or involving a combination of social and economic features. It can be a combination of variables such as occupation, education, income, wealth, housing, sanitation, participation in community life as well as other social and cultural attitude and values. "The socio-economic status was the position an individual occupies in a society concerning the amount of cultural possession, effective income, material possession, prestige and social participation" (Ovwigho, 2011). Socio-economic background of an individual indicates the status of an individual in the society. The importance of socioeconomic studies of an individual, group and community has been widely recognised.

The main problem in the society is that there is no proper awareness and understanding the tribal people. In government point of view, even the government has taken lot of schemes benefiting to them; the whole benefits not reached them properly. Most bankers hesitate to give loans to them, because they don't have proper income and status in the society. The aim of the study was to assess the socio-economic status of tribal people in Bahraich District in India. In addition, the study focuses on the need and importance of financial and non-financial support to overall well-being and empowerment of the tribal people in Bahraich District.

\section{MATERIALS AND METHODS}

The basic objective of this study was to assess the Socio economic status of Tharu Tribes of Bah- raich District of Uttar Pradesh. Looking to the nature of study descriptive research design was adopted. For the study of Socio economic status of adult tharu tribes, There are 15 blocks in Bahraich district, its Nanpara tehsil has four blocks, in these four blocks only Mihinpurwa has tharu population. According to census 2011, total population of Mihipurwa block was 6044 .. Random sampling was adopted for the study and accordingly 356 samples were selected from Shivpuri, Vishnapur, Fakeerpuri and Bardiya villages. 89 respondents were selected from each village. To classify the socio-economic status of the respondents, socio economic status scale for rural areas primarily developed by Uday Pareek (1964) has been adopted with subject to preliminary test and slight modifications per the need of the study. The key aspect of this scale used for data collection included nine main items such as (1) Income (2) Family type (3) Education (4) Occupation (5) Land (6) Farm power (7) Material possessions (8) House (9) Social participation of the respondent. Field data was collected by direct observation and personal interview method using Uday Pareek scale for the assessment of socio economic status. If the score of the respondent range was 26-32. It was considered that the respondent belonged to the Upper middle Class. Similarly the score range between 21-26 was considered as belonging to middle class. The score range between 15-20 was considered as respondents belonging to LowerMiddle Class; and the score between 08-14 was considered as belonging to lower class

\section{RESULTS AND DISCUSSION}

During the study $59.26 \%$ respondents belonged to female category and $40.74 \%$ respondents belonged to male categoty. Similar findings were also observed by Komuha (2014) on mao naga farmers in Senapati district of Manipur where 74\% respondents belonged to male category and $26 \%$ resondents belonged to female catogory.

Component 1: Family income: Income is an important indicator to study socio-economic condition. Income refers to the total monetary received by all member of the family from all the sources.

Table 1. District wise population of Tharus in Uttar Pradesh (2001).

\begin{tabular}{lll}
\hline SI. No. & District & Population \\
\hline 1 & Lakhimpur Kheri & 37949 \\
2 & Balrampur & 19347 \\
3 & Bahraich & 8558 \\
4 & Shravasti & 4756 \\
5 & Maharajganj & 2564 \\
6 & Scattered Tharus in then & 32362 \\
& districts & \\
& Total population & $\mathbf{1 0 5 5 3 6}$ \\
\hline
\end{tabular}

Source: Directorate of Tribal Development, Uttar Pradesh, India 
Kumari, J. et al. / J. Appl. \& Nat. Sci. 10 (3): 939 - 944 (2018)

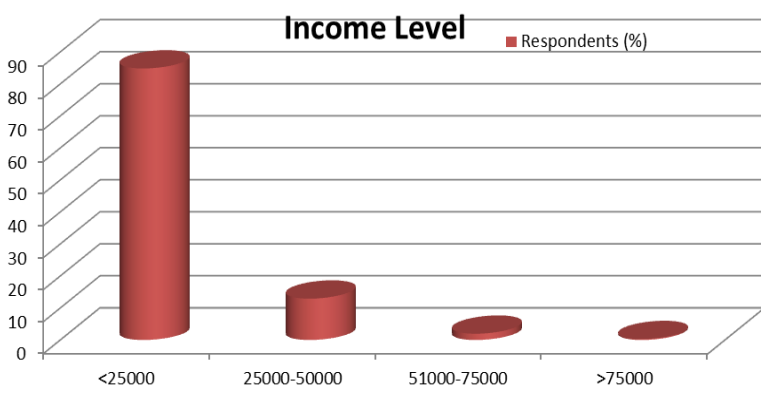

Fig. 1. Distribution of respondents according to family income of Tharu Tribes.

The imputed values of home grown rice, vegetables, wheet, firewood and other freely received items or which are not bought, are not included in the income calculated. The results revealed that $84.83 \%$ of respondents had income below Rs. 25000.00 per year and 12.92 per cent respondents had monthly income between Rs. 25000.00Rs. 50000.00 where as $1.96 \%$ of respondents had income between Rs. 51000-75000 and 0.29\% had income more than Rs. 75000 per year (Fig.1). Same finding observed by Pulla (2013) on the scheduled tribes in Visakhapatnam district of Andhra Pradesh State (India.) and observed that 49 per cent of the households are having the income in the range of below Rs.50,000, 40 per cent of the households are in the range of Rs.50,000 to Rs. 75,000 and only 11 per cent of the households are in the high range that is more than Rs. 75,000

Component 2: Family type: The family type refers to the family being nuclear or joint. $81 \%$ of the respondents lived in a nuclear family and only $19 \%$ respondents belong from joint family. No respondent live in an extended family (Fig.2). Similar finding were observed by Komuha (2014) on mao naga farmers in senapati district of Manipur

Table 2. Distribution of respondents on the basis of education of Tharu tribes.

\begin{tabular}{lll}
\hline Level of education & No. of respondents & \% \\
\hline Illiterate & 190 & 53.38 \\
Can read only & 12 & 3.38 \\
Can read and write & 28 & 7.87 \\
Primary & 31 & 8.70 \\
Middle education & 24 & 6.74 \\
High school & 61 & 17.13 \\
Graduate and above & 10 & 2.80 \\
Total & $\mathbf{3 5 6}$ & $\mathbf{1 0 0}$ \\
\hline
\end{tabular}

Table 3. Distribution of respondents on the basis of occupation of Tharu tribes.

\begin{tabular}{lll}
\hline Occupation & No. of respondents & $\mathbf{\%}$ \\
\hline Wage labourers & 121 & 34 \\
Artisan & 4 & 1.12 \\
Trader & 4 & 1.12 \\
Pretty employee & 4 & 1.12 \\
Farmer & 220 & 61.80 \\
Service holder & 3 & 0.84 \\
Total & $\mathbf{3 5 6}$ & $\mathbf{1 0 0}$ \\
\hline
\end{tabular}

- Nuclear Family u Joint Family

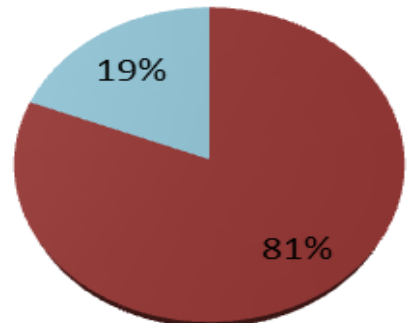

Fig.2. Distribution of respondent on the basis family type of Tharu tribes.

where $89 \%$ of the respondents lived in a nuclear family and only $11 \%$ live in a joint family (fig. 2).

Component 3: Education: Table 2 shows the highest academic qualification of the respondents. The findings indicate that $53.38 \%$ respondents were illiterate; $20 \%$ were upto primary level 23.87 $\%$ respondents upto high school and only $2.8 \%$ studied upto graduation. Similar findings were observed by Sujith et al (2016) for schedule tribes of Velugodu, Andhra Pradesh, in India. They concluded that in the state of Andhra Pradesh majority $(72 \%)$ of the population are illiterate. Of them $61.5 \%$ of the population are illiterate beyond ten years of their age. $22.4 \%$ of the population had primary education. Among them $40.7 \%$ could not pursue secondary education. Secondary education was completed by $4.68 \%$ of the population. $56.2 \%$ of these did not pursue higher secondary education. Only two persons and one person had higher secondary and graduate education respectively. Similar study proposed by Rao (2014) on tribal population of Vizianagaram district of Andhra Pradesh In the sample area, out of 200 households, the illiterate heads are 109 (54.50\%). 67 heads of the households had primary and secondary educational qualifications and 24 heads of the households had higher educational qualification in the sample area.

Component 4: Occupation: The finding indicated

Table 4. Distribution of respondents on the basis of land holding of Tharu tribes.

\begin{tabular}{lll}
\hline $\begin{array}{l}\text { Land holding } \\
\text { (in Acre) }\end{array}$ & No. Of respondents & $\mathbf{\%}$ \\
Landless & 24 & 6.75 \\
Upto 1 & 165 & 46.34 \\
1 to 2 & 142 & 39.89 \\
2 to 3 & 18 & 5.05 \\
3 and above & 7 & 1.97 \\
Total & $\mathbf{3 5 6}$ & $\mathbf{1 0 0}$ \\
\hline
\end{tabular}

Table 5. Distribution of respondents on the basis of farm power of Tharu tribes.

\begin{tabular}{lll}
\hline Farm power & No. of respondents & $\%$ \\
\hline No draught animal & 261 & 73.31 \\
1-2 draught animals & 71 & 19.94 \\
3-4 draught animals & 17 & 4.78 \\
5-6 draught animals & 07 & 1.97 \\
Total & 356 & 100 \\
\hline
\end{tabular}


Kumari, J. et al. / J. Appl. \& Nat. Sci. 10 (3): 939 - 944 (2018)

Table 6. Distribution of respondents on the basis of Material possession of Tharu tribes.

\begin{tabular}{lll}
\hline Material possession & $\begin{array}{l}\text { No. of re- } \\
\text { spondents }\end{array}$ & \\
\hline $\begin{array}{l}\text { Traditionally household neces- } \\
\text { sities and agricultural imple- }\end{array}$ & 350 & 98.31 \\
ments for production of food & & \\
Modern household necessities & 24 & 6.74 \\
Luxurious items & 6 & 1.68 \\
\hline
\end{tabular}

Table 7. Distribution of the respondents on the basis of housing of Tharu tribes.

\begin{tabular}{lll}
\hline Types of house & No. of respondents & $\%$ \\
\hline No house & 02 & 0.57 \\
Hut & 12 & 3.37 \\
Kutcha house & 292 & 82.03 \\
Mixed house & 18 & 5.05 \\
Pukka house & 32 & 8.98 \\
Mansion & 0 & 0 \\
Total & 356 & 100 \\
\hline
\end{tabular}

that the $61.80 \%$ respondents were farmers. $34 \%$ respondents were work as wage labourers. Only $1.12 \%$ respondents perform the work as artisan particularly mat making. $1.12 \%$ respondents were trader and $1.12 \%$ were pretty employee. Only $0.84 \%$ respondents were service holder (Table 3 ). Similar findings were reported by Rajkumar et al (2013) on schedule tribes of Vizionagram district of Andhra pradesh occupational pattern of heads of the sample households in the study area. It revealed that, more than 94 per cent of the sample households were male headed, 83 per cent of the heads of the sample households were agricultural labour that was having some land and also going for agricultural labour as majority of their incomes were derived from wage labour they were classified as agricultural labour and the remaining was wage labour. All the female heads of the households were agricultural labour. Similar results were found by Debjani (2012) study conducted on Socio-economic Status of Scheduled Tribes in Jharkand. This clearly indicates that, agriculture was the main source of livelihood in the study area, where majority of the sample households were depending on agriculture and land related activities for their livelihood. Similar findings by Akash raj et al (2013) revealed that $45.65 \%$ (912 individual) were working population and $54.35 \%$ (1,086 individual) were dependent which includes children, older adults and homemakers. Among the working population major proportion were engaged as agriculture labours (55.70\%), followed by cultivators $(17.98 \%$ ) and Non-agricultural labours (13.16). The overall revelation of the study is that the selected tribes were engaged in the low profile jobs.

Component 5: Land holding: The above table shows that $6.75 \%$ respondents do not have own individual agricultural land.86.23\% were marginal land holders of upto 2 acres; only $5 \%$ respondents have own land of $2-3$ acres and only $1.97 \%$ re-
Table 8. Distribution of respondents on the basis of social participation of Tharu tribes.

\begin{tabular}{lll}
\hline Social participation & $\begin{array}{l}\text { No. of re- } \\
\text { spondents }\end{array}$ & \\
\hline Member of 1 organisation & 36 & 10.12 \\
Member of $>1$ organisa- & 0 & 0 \\
tion & 1 & 0.28 \\
Office bearer & & 0 \\
Wider public leader & 0 & 89.60 \\
Not a member at all & 319 & \\
Total & $\mathbf{3 5 6}$ & $\mathbf{1 0 0}$ \\
\hline
\end{tabular}

Table 9. Overall socio-economic status of the respondents.

\begin{tabular}{llll}
\hline Category & Score & $\begin{array}{l}\text { No. of } \\
\text { respond- } \\
\text { ents }\end{array}$ & \\
\hline Upper-middle class & $26-32$ & 1 & 0.28 \\
Middle class & $21-25$ & 19 & 5.33 \\
Lower -middle class & $15-20$ & 269 & 75.56 \\
Lower class & $08-14$ & 67 & 18.83 \\
Total & & $\mathbf{3 5 6}$ & $\mathbf{1 0 0}$ \\
\hline
\end{tabular}

spondents have agricultural land of above 3 acres (Table 4). Rajkumar et al (2013) conducted a study on schedule tribes of Andhra Pradesh in Vizionagram district and founded that the land ownership details of the sample households in the study shows that, more than 11 per cent of sample households do not have any land. Among sample respondents having land, among those only more than 60 per cent were very small farmers and the remaining owned more than 2 acres of land. Marginal farmers were accounted for more than 48 per cent of the farmers in the less than one acre range does not have ownership rights. However, there was 61 per cent owned sample were not having ownership rights for their lands in the study area for more than 1 acre range, As a whole more than 37 per cent of the land owned sample households do not have ownership rights. Akash Raj and Mahesh (2016) also concluded that among 221 land holders 184 (82.88 \%) were marginal farmers, who own less or equal to an acre of land; 37 (16.67\%) were small farmers, who have between 1 and 2 acres; and only one $(0.45 \%)$ is semi medium farmer who has between 2 and 4 acres of land. From the information collected about the landholding, it is inferred that more than half of the total study population is landless and major proportion of landholders were marginal farmers.

Component 6: Farm power: The findings indicate that the $73.31 \%$ respondents do not have any draught animal. $19.94 \%$ respondents have 1 2 draught animals; $4.78 \%$ own 3-4 draught animals. Only $1.97 \%$ respondents have 5-6 draught animals (Table 5). A similar study conducted by Jajuo Komuha (2014) on mao naga farmers in senapati district of Manipur indicate that $75.3 \%$ respondents do not have any draught animal. 
Therfore, when required they have to hire other's animals to plough the fields. $16.7 \%$ respondents have own 1-2 draught animals; and $8 \%$ have own 3 or more draught animals.

Component 7: Material possession: The findings indicate that the $98.31 \%$ respondents possess one item or the other of traditional household necessities and agricultural implements for production of food.

While $6.74 \%$ of the respondents possessed at least one important item of modern household necessities such as mobile telephone, LPG etc. Only $1.68 \%$ respondent have luxurious items such as television, refrigerator any four wheeler etc (Table 6). Similar findings were observed by Komuha (2014) on mao naga farmers in senapati district of Manipur where all the respondents possess one item or the other of traditional household necessities and agriculture implements for production of food. While $79 \%$ of the respondents were have modern household necessities but more than $80 \%$ of the respondents do not have any luxurious items such as television etc. The use of wshing machine and refrigerator by any household were nil. Rajkumar et al (2013) also concluded that that, the durable assets owned by the sample households in the study area, it shows that the assets owned by the sample households was lacking information technology era like television. However most of the sample did not have even bicycle also. The common feature owned by sample households was bullock carts.

Component 8: Housing: In above table we see that $8.98 \%$ of the respondents live in a pucca house. Majority $82.03 \%$ respondents live in kutcha house. $5 \%$ respondents live in a mixed house and $3.37 \%$ respondents live in hut. Only few respondents $0.57 \%$ do not have their own houses (Table 7). A similar study conducted by Jajuo Komuha (2014) on mao naga farmers in senapati district of Manipur indicated that $1.6 \%$ of the respondents lived in a pacca house, $96.4 \%$ lived in a kutcha houses and $2 \%$ do not have their own houses

Component 9: Social participation: The study on the social participation of the respondents in above table indicates that $10.12 \%$ respondents were members in either social or political or voluntary organisation; $0.28 \%$ of them hold office in one or more organisation. $89.60 \%$ respondents were formally neither member of any organisation nor holding any office (Table 8). Similar finding were observed by Komuha (2014) on Mao naga farmers in Senapati district of Manipur, where $17.7 \%$ of the households' heads were members in either social or political or voluntary organization, $0.6 \%$ of them were engaged in more than one organization, $0.7 \%$ of them hold office in one or more organization like village or church chairman/ secretary, and only $1.3 \%$ of them were involved in wider leadership beyond his own village. The rest
$79.7 \%$ were formally neither member of any organisation nor holding any office. But, by religion, they were all attached to their religious institutions and by customary, they all belongs to a clan group. Table 9 indicates that $0.28 \%$ respondent belongs to upper middle class, $5.33 \%$ were middle class, $75.56 \%$ belongs to lower middle class and $18.83 \%$ lower class. Similar study conducted by Komuha (2014) on mao naga farmers in Senapati district of Manipur indicated that all the mao farmers belonged to three categories i.e middle class; lower-middle class and lower class. $5 \%$ belonged to middle class and $95 \%$ were below middle class ( $77 \%$ lower middle class and $18 \%$ lower class).

\section{Conclusion}

The study emphasized the need for tribal development in India. Measuring the socio-economic conditions, it can be concluded that all the tharu tribes of the area belonged to four categories viz: Upper Middle Class, Middle Class, Lower Middle Class and Lower Class. $0.28 \%$ respondent belonged to upper middle class, $5.33 \%$ are middle class, $75.56 \%$ belongs to lower middle class and $18.83 \%$ lower class. The findings can be beneficial for implementing projects that can help in improving their situation of backwardness. Their low level of economic activities, social backwardness, low level of literacy, poor health, unemployment conditions make it vital for a systematic process of tribal development. Agriculture covers large share of occupation in the study area. Agricultural training on seeds, harvesting fertilizers etc. should be launched for the improvement of agricultural system. The farmers should encourage to produce cash crops. Irrigation facility should provide so that people can produce various crops in winter season too. The raising of the socioeconomic status of tharu tribes will assist policy makers and local development practitioners to design appropriate and effective policies and programmes in this regard.

\section{ACKNOWLEDGEMENTS}

I would like to express my gratitude and appreciation to all the authors in making this research paper possible. Firstly, I want to express my sincere gratitude to my research supervisor Dr. Ritu Prakash Dubey for her valuable guidance and support. I am also thankful to Dr. Dipak Bose, Associate Professor of agriculture extension and communication, for his guidance and support which has helped me to complete my work. My heartful thanks to my best friend Ms. Vandana Gupta who came across and rendered their help during the research work.

\section{REFERENCES}

1. Agarwal, O.P., Bhasin, S.K., Sharm,. A.K., Chhabra, P., Agarwal, K., Rajoura, O.P. (2005). A new instru- 
ment (scale) for measuring the socioeconomic status of a family: Preliminary study. Indian $J$ Community Med, 30, 111-114.

2. Akash Raj, D.P., and Mahesh, T.M. (2016). Socioeconomic status of students tribes in mysuru districtKarnataka. International journal of development research 6(12), 10893-10896.

3. Debjani, R. (2012). Socioeconomic Status of schedule Tribes in Jharkhand. Indian Journal of Spatial Science, 3 (2), 26-34.

4. Ghoshal, S.L.(1986). Tribal Jhabua in transition: some factors, Kurukshetra. Ind.J.Rur. Devt. XXXIV, 4-27

5. Indian Government. T 00-005: total population, population of scheduled castes and scheduled tribes and their proportion to the total poulation. (online). Available: http://www.censusindia.net/t_00_005.

6. Jajuo, komuha (2014). A study the socio-economic condition of Mao naga farmers in senapati district of Manipur. (Doctoral dissertation). Assam university, Assam

7. Jelliff, B.D., and Jelliff, E.F.P.(1989). Direct assessment of nutritional status: Community nutritional assessment with special reference to less technically developed countries. Oxford University Press, 64-91, Oxford New York, Tokyo.

8. Ovwigho, B.O. ( 2011). Construction of a Socioeconomic Status scale for Heads of Rural Farm Families in the North Agricultural Zone of Delta State, Nigeria. J Hum Ecol, 33(2), 113-118.

9. Pattanaik, D. ( 2007). Liquor culture among tribals and Government excise policy: an analytical study, M.Sc Thesis, Council of Analytical Tribal Studies (COATS), Koraput, Orissa (India).

10.Pulla., Rao, (2013).Socioeconomic Status of Scheduled Tribes. MERC Global's International Journal of Management, 1(1):35-50.

11.Rajkumar, p., Pulla Rao., D., Jayanand Kumar., p. (2013). Analysis os socio economic status of schedule tribes in Andhra Pradesh. International journal of development research, 3(11):136-140.

12.Rao., D. Pulla. (2014). Socio - economic status of scheduled tribes in vishakhapatnam district of Andhra Pradesh. Journal of social welfare and management,6 (4).

13.Sethia, S., and Joshi, P. ( 1990). Microlevel planning tribal areas. Yojana, 34 (9):24-25.

14.Sharma, J.C. ( 1995). Nutritional status, health, growth and development of a central Indian tribe with special reference to environment and genetic risk factors. In; anthropology of tribal health and medicine in forest environment by viswanathan Nair, N. KIRTADS, 55-60.

15.Sujith., Kumar., S. Dondapati.,and Keerthinmayee., Karimaddela. (2016). Socio-demographic and health profile of schedule tribes of Velugodu, Andhra Pradesh, India. Int J Community Med Public Health. 3 (9):2615-2620

16.Uday Pareek Scale for Rural Areas., 2012, Retrieved from htt://publichealth-india.blogspot.in//02/udaypareek-scale-for-rural-areas.html. 